\section{DISEASES OF THE HEART AND CIRCULATION}

By Paul Wood, O.B.E., M.D., F.R.C.P. Second edition. Pp. xxxviii + I005, with $5^{1} 3$ illustrations. London: Eyre and Spottiswoode. 1956. £5.

The first edition of this book immediately established itself as the leading British exposition of the subject. The second edition is even better.

With I,000 pages it might be regarded as an expensive book were there not nearly 500 illustrations, nearly all of which add meaning to a text which is crisp and packed with information. Since there are also $\mathrm{I}, 900$ references and a comprehensive index one has to accept that the book is very good value. The extent of the author's experience, which it reveals, and the number of his other publications, which it quotes, must make even those who do not know him marvel at his energy, and those who do wonder where he finds time for all the other work he does.

The chief claim to originality is that this textbook brings the knowledge acquired in the back room to the bedside. One senses all the time the hard thinking that has gone into the interpretation of physiological measurements in the light of clinical experience. The author's ingenuity effervesces on every page - the living Wood hacking away the dead.

There is a suspicion that some of the physiology is not that of the physiologist. Most of the author's 'Appreciation of Mitral Stenosis' turned into an appreciation of the pulmonary arteriole, and this in turn derived from figures obtained at cardiac catheterization. And yet, for cardiac catheterization, a departure from physiology by premedication with omnopon is recommended. No mention is made of the importance of measuring oxygen uptake at the same time as the mixed venous and arterial blood samples are taken. A Benedict-Roth spirometer, with all its well-known inaccuracies in this context, lurks ominously in the background of the photograph of the catheterization ' set-up.'

It is as an usually enlightened clinician that the author has his main contribution to offer. Despite his modest claim ' to expect that consulting cardiologists might find (the book) of value would be presumptuous,' the present reviewer prefers the conclusion of the review of the first edition in the British Heart Fournal: 'A work which no cardiologist who aspires to keep abreast of his subject can afford to be without.'

M.B.M.

\section{CARDIOLOGY}

By William Evans, M.D., D.Sc., F.R.C.P. Second edition. Pp. ix +574 , with 569 illustrations. London: Butterworth \& Co. Ltd. 1956. £4 I2s. 6d.

This book is already well known. The new edition claims to include ' $a$ mass of fresh and upto-date material ' and guidance as to the interpreta- tion of the newer aids and methods used in the investigation of cardiac function and the selection of patients for surgery in certain forms of heart disease. In fact, the book is more nearly a Rep. Mist in a larger bottle. A fascinating mixture it is, including, among many other things, sound common sense and clinical wisdom, empiricism, special electrocardiographic leads which no one else uses, and a very real interest in the patient's protection from uncomfortable or potentially dangerous investigation. The Celtic flavour adds body. The dispenser's D.Sc. will not, however, lull the cautious reader into swallowing some of the science. There is a small precipitate of new technical matter which detracts from the value of the mixture. (One has the impression that, unlike the rest, it is not made on the premises.)

To those who look on the heart as a purveyor of interesting noises and fascinating electricity this is the book to have, though they will learn nothing of the mechanisms. Those who want to learn of its pumping capabilities in health and disease should look elsewhere. For those acquiring a philosophy of medicine there is much useful help.

M.B.M.

\section{HUMAN OVULATION AND FERTILITY}

By Edmond J. FarRis, Ph.D.,. Pp. xiii + I59. London: Pitman Medical Publishing Co. Ltd. 1956. 5os.

The main purpose of this book is to popularize and a make a plea for the adoption of the rat hyperemia test for the determination of the precise time of ovulation in the sterile woman. The test is carried out on Wistar rats and a full description of the technique of the test is given.

Many hundreds of results are (not too critically) analysed.

Claims are made that the test is far superior to temperature records kept by the woman.

There are some beautiful plates of ovulating ovaries.

The author claims that the test will show when ovulation will take place as opposed to has taken place in any particular woman for any particular cycle and he believes that even the hour can be predicted.

A claim is made that the interval ovulation to the next menstruation is not constant for all women and that conception can only occur if the ovulation for that particular month is accurately known.

There are many other interesting theories advanced such as that the duration of gestation is on an average longer in younger than in older women.

A pregnancy diagnosis method by colour matching is described.

To the reviewer's mind, far too great emphasis is laid on the role of artificial donation of semen.

The book is an interesting contribution to the study of infertility. 